\title{
Strukturasi Media Daerah dalam Regulasi di Era Konvergensi dan Disrupsi
}

\author{
Nunik Hariyani ${ }^{1}$, Hermin Indah Wahyuni ${ }^{2}$, Christian Budiman ${ }^{3}$ \\ ${ }^{1}$ Mahasiswa Program Studi Doktor Kajian Budaya dan Media Sekolah Pascasarjana \\ Universitas Gadjah Mada dan Dosen Program Studi Ilmu Komunikasi \\ Fakultas Ilmu Sosial dan Ilmu Politik Universitas Merdeka Madiun, Universitas Merdeka Madiun, Jl.Serayu 79, \\ Madiun, 63133 \\ E-mail: hariyani_nunik@yahoo.com \\ ${ }^{2}$ Dosen Program Studi Kajian Budaya dan Media Sekolah Pascasarjana \\ Universitas Gadjah Mada dan Program Studi Ilmu Komunikasi \\ Fakultas Ilmu Sosial dan Ilmu Politik Universitas Gadjah Mada, Jl.Sosio-Justisia, Bulaksumur, Yogyakarta, \\ 55281 \\ E-mail: herminkilo12@gmail.com \\ ${ }^{3}$ Dosen Program Studi Kajian Budaya dan Media Sekolah Pascasarjana Universitas Gadjah Mada, \\ Jl.Teknika Utara, Sleman, Yogyakarta, 55281 \\ E-mail: kbm_spsugm@yahoo.com
}

\begin{abstract}
This research moves from the reality of media life of area in Madiun of East Java which experiencing changes in line with social politics situation of Indonesia. Media is a commodity that can be exchanged, it is exploit all the potential and various social forces that exist. This study aims to know and analyze the stuctutation of regional mass media, the weekly magazine of Kridha Rakyat in Madiun, East Java. The theory used is the political economy approach that is the structuration according to Vincent Mosco. The method used is descriptive qualitative with data collection technique through interview, observation, ethnography and content analysis. The results show that the media perform the process of production and reproduction of power structures by media rulers (owner) by utilizing media agents and social relationship with other structure outside media. The media produces a series of power-reinforcing powers that ultimately reinforce the media's position.
\end{abstract}

Keywords : Structuration; Regional Mass Media; Weekly Magazine.

\section{A. LATAR BELAKANG}

Sejak kelahirannya pada masa kolonial tahun 1948, petumbuhan media cetak di daerah tetap tinggi. Ditengah digitalisasi dan maraknya media cetak Indonesia yang tutup akhir-akhir ini, kajian media daerah menjadi menarik untuk dikaji. Menurut ketua Dewan Pers, Yosep Stanley Adi Prasetya, tanggal 21 Februari 2018, pertumbuhannya media cetak mencapai 47.000. Jumlahnya melebihi yang ada di Amerika Serikat yang tidak lebih dari 100 media. Jawa Timur sebagai salah satu provinsi di Indonesia yang diapit oleh provinsi Jawa Tengah dan Provinsi Bali menjadi wilayah strategis untuk kehidupan media (pers). Jawa Timur menjadi pilihan bagi para investor dan pengelola media untuk menerbitkan media cetak daerah secara mingguan. Data dari dewan pers sampai tahun 2017, dari 148 media cetak (harian, mingguan dan bulanan) prosentase media cetak yang terbit mingguan sebesar 55\%, terbit harian sebesar $25 \%$ dan yang terbit bulanan sebesar $20 \%$.

Tahun 2016, Jawa Timur memiliki 148 media cetak, tersebar di lima Badan Koordinasi Wilayah (Bakorwil). Jawa Timur juga memiliki Indeks Kemerdekaan Pers (IKP) tertinggi yaitu mencapai 61,90 (www.ubaya.ac.id). Dari lima Bakorwil di Jawa Timur, Madiun adalah wilayah pilihan potensial untuk tumbuhnya media daerah. Salah satu media daerah yang muncul dari madiun adalah Kridha Rakyat. Madiun menjadi pilihan karena dari Bakorwil I Madiun, Bakorwil II Bojonegoro, Bakorwil III Malang, Bakorwil IV Pamekasan dan Bakorwil V Jember, Madiun adalah pusat Bakorwil I terluas di Jawa Timur. Madiun memiliki 11 wilayah kota/kabupaten (Kota Madiun, Kabupaten Madiun, Kabupaten Magetan, Kabupaten Ngawi, Kabupaten Ponorogo, Kabupaten Trenggalek, Kabupaten Tulungagung, Kabupaten Pacitan, Kabupaten Blitar, Kota Blitar dan Kabupaten Nganjuk). Madiun menjadi sasaran pasar strategis beberapa media cetak daerah. Selain media cetak mingguan Kridha Rakyat (satu-satunya yang berkantor redaksi di Kabupaten Madiun), juga 
Website : http://yustisia.unmermadiun.ac.id/index.php/yustisia

terdapat tiga media cetak lain yaitu Harian Radar Madiun, Mingguan Swara Rakyat dan Mingguan Benar beredaksi di Kota Madiun. Sehingga Madiun menjadi sasaran pasar banyak media cetak.

Dari hasil pengamatan langsung pada komunitas wartawan, wartawan biro-biro media cetak lain dari luar Kabupaten Madiun banyak yang berebut mencari berita dan iklan di Kabupaten Madiun. Media cetak tersebut antara lain dari kantor redaksi di Surabaya yaitu Mingguan Soerabaia Newsweek, Mingguan Jatim Pos, Mingguan Awas, Mingguan Berita Lima, Mingguan Suksesi, Mingguan Bidik Nasional, Mingguan Memo, Harian Bhirawa, Harian Duta Masyarakat, Harian Pojok Kiri. Biro lainnya dari redaksi di Mojokerto yaitu Mingguan Radar Indonesia, Mingguan Radar Bangsa, Mingguan Realita Masyarakat. Sedangkan dari kantor redaksi di Kediri yaitu Mingguan Suara Media Nasional, Mingguan Metro Jatim. Selain itu, dari Redaksi Gresik yaitu Mingguan Jagad Pos.

Padahal selain jumlah, keberadaan media cetak daerah sebagai salah satu media massa memiliki peran sentral dalam kehidupan masyarakat daerah. Media cetak daerah dituntut menjadi salah satu sumber kekuatan membangun daerah. Sasaran menuju pencapaian "good local governance" ditentukan oleh sejauhmana peran dan kontribusi media cetak daerah. Sehingga, keberadaan media cetak daerah sangat penting diperhatikan ditengah arus konvergensi dan konglomerasi media. Apalagi di era digitaliasi dan era disrupsi sekarang ini, media cetak daerah menjadi bahan kajian yang dinamis dalam semua sisi kehidupan di daerah, yaitu interaksi antarmedia dengan nilai-nilai daerah sebagai entitas daerah. Proses produksi dan distribusi media cetak daerah yang dikemas dalam bentuk berita maupun hiburan, memberi gambaran dan citra realitas sosial individu dan masyarakat daerah secara kolektif. Media cetak daerah termasuk sarana pengembangan kebudayaan daerah, bukan saja dalam bentuk seni dan simbol daerah, namun juga pengembangan tata cara, mode, gaya hidup dan norma-norma daerah. Media dipandang menurut McQuail (2002 : 66) dalam bukunya Mass Communication Theories adalah window on event and experience, sebagai jendela yang memungkinkan khalayak "melihat" apa yang sedang terjadi di luar sana ataupun pada diri mereka sendiri.

Akan tetapi, fenomena sosial tentang media cetak daerah dengan karakteristik khas sebagai institusi sosial media massa di daerah ternyata tidak hanya menjalankan fungsi fungsi sosial sebagai penyampai informasi dan fakta kepada publik, tetapi juga menjalankan fungsi ekonomi dan fungsi ideologis. Secara fungsi sosial menurut Jack Snyder (2003, sebagaimana dikutip Tim LSPP, 2005: 8) peran positif yang dapat dimainkan media daerah, seperti sebagai pendidik, pengidentifikasi masalah, penyedia forum, dan penguat (revitalitator) sosiokultural bagi komunitasnya. Pada pasal 6 Undang - Undang No 40 Tahun 1999 tentang Pers juga menegaskan peran media untuk memenuhi hak masyarakat untuk mengetahui, menegakkan nilai dasar demokrasi, mendorong terwujudnya supremasi hukum, dan Hak Asasi Manusia (HAM), serta menghormati kebhinekaan, mengembangkan pendapat umum berdasarkan informasi yang tepat, akurat dan benar, melakukan pengawasan, kritik, koreksi, dan saran terhadap hal-hal yang berkaitan dengan pemerintahan, bisnis, kepentingan umum,serta untuk memperjuangkan keadilan dan kebenaran. Robert Dahl (seperti dirujuk Oetama, 2001:76) menyebut peran media yang bebas sebagai "the availability of alternative and independent sources of information". Peran utama ini bersinergi dengan prinsip-prinsip good local governance seperti partisipasi, transparansi, dan akuntabilitas di tingkat daerah.

Sedangkan secara fungsi ekonomi dan fungsi ideologis media, pertimbangan pertumbuhan ekspansi pasar dan profit menjadi pertimbangan perluasan kepentingan oleh media, termasuk oleh media cetak daerah. Pada titik tertentu, produk yang dihasilkan media pada dirinya akan bersifat ideologis (Littlejohn, 2002 : 217). Ideologi sendiri direpresentasikan sebagai the social cement yang mengikat bersama berbagai aliansi kelas yang berbeda (Stevensen, 2002). Media daerah pada akhirnya memainkan peran penting dalam instrument hegemoni, yang menurut Raymond Williams konsepnya akan terlihat pada tiga proses kultural yaitu tradisi, institusi dan formasi (Stevensen, 2002). Sebagai instrument untuk menyampaikan pesan ideologis, agen-agen media cetak daerah bisa jadi diciptakan dan didominasi sebagai alat untuk mencitrakan, merekayasa kesepakatan dan pengontrol informasi dari kepentingan-kepentingan blok hegemoni ataupun blok kontra hegemoni.

Dalam hal tertentu, media bukan lagi sekedar realitas yang netral dan bebas kepentingan, tetapi media massa justru menjadi realitas yang rentan dikuasai oleh kelompok yang lebih dominan dan berkuasa (Rogers, 1994:102-125). Simulasi, tabloidisasi dan komodifikasi diracik dan diolah menjadi satu di dalam media. Sedangkan reproduksi realitas dalam media pada dasarnya dan umumnya akan sangat dipengaruhi oleh bahasa (Littlejohn, 2002:210-211). Isi berita media daerah sendiri akan sangat dipengaruhi oleh basis ekonomi dari institusi media yang memproduksi berita, sehingga wartawan dengan produk beritanya berada di bawah kendali pemilik modal. Diperlukan paradigma penelitian dan metode penelitian yang mampu menelanjangi, menggali dan mengeksplorasi struktur, rasionalitas dan ideologi yang kesemuanya bersifat laten termuat dalam media (Dedy N. Hidayat, $2000:$ 127-164). 
Website : http://yustisia.unmermadiun.ac.id/index.php/yustisia

Menurut teori Marxis tentang posisi media dalam sistem kapitalisme modern, mengatakan bahwa media massa merupakan kelas yang mengatur. Kelas yang dapat mengatur segala aspek yang ada didalam suatu negara dan dapat mempengaruhi unsur-unsur dalam bidang perekonomian maupun politik pemerintahan. Media massa dapat dikatakan sebagai lembaga kunci dari masyarakat modern. Artinya, media daerah juga dapat menjadi ruang publik utama dalam menentukan dinamika sosial, politik dan budaya daerah. Media daerah memiliki kemampuan menyebarkan dan memperkuat struktur ekonomi dan politik daerahnya.

Sedangkan menurut pandangan konstruktivis, berita pada media massa adalah hasil konstruksi sosial dimana selalu melibatkan pandangan, ideologi, dan nilai-nilai dari wartawan dan media itu sendiri. Media tidak hanya memiliki peran sebagai penyalur pesan, melainkan sebagai subjek dalam konstruksi sosial, yang memiliki pandangan sendiri dan keberpihakan. Artinya, media massa di daerah juga merupakan aktor konstruksi sosial yang mendefinisikan realitas daerahnya yang sangat tergantung pada manusia sebagai aktor media. Menurut Peter L. Berger dan Thomas Luckmann di bukunya yang berjudul The Social Construction of Reality mendefinisikan manusia dengan istilah dialektis, dinamis dan plural. Sehingga dialektis, plural dan dinamisnya aktor media dalam memproduksi berita yang dibaca dari media massa tidak hanya memberikan realitas sosial, melainkan juga menunjukan konstruksi sosial dari media tersebut. Media massa membentuk realitas sosial lewat pemberitaan yang dilakukannya.

Di sisi lain, fakta di daerah penerapan model pengaturan kemerdekaan pers yang sesuai Undang-Undang Nomor 40 Tahun 1999 tentang Pers, sebagai self regulation bergantung pada ideologi dan diamika politik daerah masing-masing. Hal ini sependapat dengan M.Rooij, mantan Pemimpin Redaksi de Nieuwe Rotterdamse Courant tentang hubungan media dengan ideologi dan dinamika politik suatu daerah. Menurutnya, ideologi yang berlaku di daerah tempat sebuah koran atau media, hadir dan beroperasi lambat laun akan mempengaruhi dan menentukan perkembangan koran atau media (Sularto, 2011:18). Kajian ini akan melihat bagaimana struturasi media daerah dengan perspektif ekonomi politik media. Berfokus kepada media cetak mingguan Kridha Rakyat yang berdiri sejak tahun 2002 di Madiun. Kridha Rakyat bertahan terbit sebagai media cetak. Media ini bertransformasi mulai dari bentuk koran tempel, bulletin, tabloid, koran sampai bentuk majalah. Kridha Rakyat satu-satunya media cetak daerah yang kantor redaksinya berada di Kabupaten Madiun.

Sedangkan beberapa media cetak yang lain hanya memiliki biro di Madiun padahal kantor redaksinya di luar Madiun. Kepemilikan Kridha Rakyat bukan dibawah korporasi kelompok/group besar media seperti Kompas Gramedia, Pos Kota, Jawa Pos News Network, Pikiran Rakyat, Femina, Media Nusantara Citra, Trans Crop, Surya Citra Media, Bakrie Grup, Lippo Grup, atau Media Grup/Surya Paloh. Oplah Kridha Rakyat sebanyak 10000 eksemplar dengan wilayah distribusi meliputi Kota Madiun, Kabupaten Madiun, Kabupaten Ngawi, Kabupaten Ponorogo, Kabupaten Magetan, dan Kabupaten Pacitan. Kridha Rakyat murni dirintis oleh Lembaga Swadaya Masyarakat (LSM) Pembinaan Ekonomi Rakyat Miskin (PERMI), jajaran redaksinya bukan tokoh atau partai politik tertentu. Selain itu, font tulisan (theme fonts) kata "Kridha Rakyat" apabila diamati sekilas mirip dengan font huruf pada kata "Kedaulatan Rakyat” pada surat kabar harian di Yogyakarta.

Sedangkan, Madiun sendiri merupakan salah satu wilayah strategis di Jawa Timur, pada saat pemerintahan kerajaan Mataram tahun 1587 menjadi salah satu eks wilayah kekuasaan Mataram. Selain itu, Madiun juga merupakan eks pusat karesidenan wilayah yang meliputi kabupaten Magetan, Ngawi, Ponorogo dan Pacitan. Secara kedudukan sekarang ini, Madiun merupakan Bakorwil I di Jawa Timur membawahi Kota Madiun, Kabupaten Madiun, Kabupaten Magetan, Kabupaten Ngawi, Kabupaten Ponorogo, Kabupaten Trenggalek, Kabupaten Tulungagung, Kabupaten Pacitan, Kabupaten Blitar, Kota Blitar dan Kabupaten Nganjuk.

\section{Strukturasi Media}

Strukturasi sebagai salah satu pintu selain komodifikasi dan spasialisasi dalam ekonomi politik media. Strukturasi berkaitan dengan relasi ide antaragen masyarakat, proses sosial dan praktik sosial dalam analisis struktur. Strukturasi dapat digambarkan sebagai proses dimana struktur sosial saling ditegakkan oleh para agen sosial, dan bahkan masing-masing bagian dari struktur mampu bertindak melayani bagian yang lain. Hasil akhir dari strukturasi adalah serangkaian hubungan sosial dan proses kekuasaan diorganisasikan di antara kelas, gender,ras dan gerakan sosial yang masing-masing berhubungan satu sama lain. Gagasan tentang strukturasi ini pada mulanya dikembangkan oleh Anthony Giddens (Mosco,1996). Sebagai bagian dari tradisi struktural, strukturasi lebih fokus pada bagimana proses berbagi makna yang terkonstruksi dalam suatu jaringan dan implikasinya bagi kehidupan organisasi (Littlejohn and Foss, 2008:262).

Dalam memahami ekonomi politik menurut Vincent Mosco adalah melihat adanya interaksi, relasi, dan negosiasi yang terjadi dalam sebuah struktur organisasi (konteks media). 
Website : http://yustisia.unmermadiun.ac.id/index.php/yustisia

"Process by which structures are constituted out of human agency, even as they provide the very "medium" of that constitution" (Mosco, 1996 : 212).

Dalam konteks ekonomi politik media, strukturasi digunakan untuk memahami relasi kekuasaan pada kelas sosial, ras, gender dan gerakan sosial yang pada akhirnya mengkristal dalam apa yang disebut hegemoni (Mosco, 1996 : 187). Melalui teori strukturasi, Mosco mencoba untuk menempatkan kajian ekonomi politik media pada titik keseimbangan. Tidak hanya melihat peran struktur dari sistem media saja, tetapi juga melihat para agen, relasi sosial, peran sosial, dan praktek sosial. Strukturasi dalam ekonomi politik media adalah sebuah pendekatan analisis sosial kritis untuk melihat komoditas, institusi, praktek dan konsekuensi dari produksi, distribusi dan penggunaan kekuasaan.

Teori strukturasi dipelopori oleh Anthony Giddens, seorang sosiolog yang mengembangkan apa yang disebutnya sebagai sosiologi sehari-hari. Sosiologi didasarkan pada pemahamannya atas strukturasi dalam sistem sosial. Teori ini ditawarkan dalam rangka membahas pertanyaan-pertanyaan seperti apakah agen manusia sebagai pelaku atau kekuatan sosial yang besarkah yang membentuk masyarakat. Teori strukturasi Giddens menunjukkan bahwa agen manusia secara kontinyu memproduksi struktur sosial (Giddens, 2010 : 12). Giddens menjelaskan bahwa struktur dan agen merupakan dualitas, bukan dualism, saling melengkapi dan tidak dapat dipisahkan. Perubahan sosial dapat diproduksi sebagai hasil dari perubahan struktur. Dan perubahan struktur akibat dari tindakan-tindakan sosial dari agen, mekanisme ini dapat terjadi berulang-ulang. Artinya, individu dapat melakukan perubahan atas struktur sosial. Dalam teori strukturasi, memungkinkan bergabungnya beberapa proses komodifikasi dan spasialisasi untuk mendapatkan keuntungan ekonomi politik komunikasi.

Dalam teori strukturasi Anthony Giddens mengaitkan stuktur dan tindakan sosial itu dalam relasi agensi, yang melahirkan praktik-praktik sosial dalam kehidupan masyarakat yang terjadi secara tersusun atau terstruktur yang berpola dan bukan sebagai suatu kebetulan. Fokus yang penting dari teori stukturasi adalah hubungan antara agensi dan struktur (agency and structure), yakni untuk menjelaskan dualitas dan hubungan dialektis antara agensi dengan struktur. Bahwa antara agensi dan struktur tidak dapat dipahami terpisah satu sama lain, keduanya merupakan dua sisi dari koin yang sama. Semua tindakan sosial melibatkan struktur, dan semua struktur melibatkan tindakan sosial. Agensi dan struktur terjalin erat dalam aktivitas atau praktik yang terus menerus dijalankan manusia. Menurut Giddens, aktivitas tidak dilakukan oleh aktor sosial namun secara berkelanjutan diciptakan ulang melalui sarana yang mereka gunakan untuk mengekspresikan diri mereka sebagai aktor. Di dalam dan melalui aktivitas-akivitas mereka, agen menghasilkan sejumlah kondisi yang memungkinkan aktivitas ini (Ritzer \& Goodman, 2008 : 569).

Gagasan yang diusung strukturasi membedakannya dengan komodifikasi atau spasialisasi. Strukturasi berhubungan langsung dengan hal-hal yang terkait dengan keagenan, hubungan sosial, praktek sosial, dan proses sosial. Maka sudah pasti ada pertanyaan-pertanyaan yang terkait dengan hal tersebut seperti pihak mana yang berpengaruh penting, bagaimana hubungan sosial diantara mereka dan bagaimana proses serta praktek sosialnya (Natsir, 2010) Manfaat strukturasi lebih kepada dua hal yaitu untuk mengkaji kekuasaan yang berlangsung dan pendekatan kritis analitis sosial. Agen dalam strukturasi pun dapat berwujud individu atau sekelompok orang. Sebagai agen, mereka merupakan aktor-aktor sosial yang perilakunya ditentukan oleh tata hubungan sosial serta penempatan dirinya di dalam masyarakat.

Teori strukturasi menunjukkan bahwa agen manusia secara kontinyu mereproduksi struktur sosial, artinya individu dapat melakukan perubahan atas struktur sosial. Giddens (2003) berpandangan perubahan dapat terjadi apabila agen dapat mengetahui gugus mana dari struktur yang dapat dimasuki dan diubah, gusus tersebut antara lain gugus signifikasi, dominasi dan legitimasi. Sedangkan sumber daya terdiri atas dua hal yaitu sumber daya alokatif dan sumber daya autoratif. Sumber daya alokatif merupakan lingkaran kontrol produk material atau tentang aspek dunia material. Sedangkan sumber daya autoratif diturunkan dari koordinasi aktifitas agen (Giddens, 1984 : 18).

\section{Masalah Penelitian dan Tujuan}

Berangkat dari latar belakang di atas, maka masalah penelitian dirumuskan sebagai berikut "Bagaimana praktik produksi dan reproduksi berita dan iklan antara agen dan struktur media di Kridha Rakyat?". Tujuan penelitian ini adalah memahami dan menganalisis relasi sosial yang dibangun media cetak daerah dengan struktur masyarakat untuk mempertahankan dan memperkokoh eksistensi medianya yang meliputi sistem produksi, distribusi dan konsumsi media. Selain itu, bertujuan memahami dan mengeksplorasi proses sosial, tindakan dan interaksi media daerah dalam menciptakan realitas yang dimiliki dan dialami media cetak.

Hasil penelitian ini diharapkan memberikan manfaat pada aspek keilmuan dan aspek metodologis. Aspek Keilmuan, penelitian ini secara teoritis, bermanfaat dalam pengembangan keilmuan kajian media dan budaya, 
Website : http://yustisia.unmermadiun.ac.id/index.php/yustisia

memberikan kontribusi pemikiran bagi pengembangan kajian budaya dan media perspektif kritis. Menghadirkan alternatif cara pandang baru dalam riset kajian budaya dan media. Dengan perspektif ekonomi politik tradisi kritis diharapkan cakupan kajian semakin luas serta hasil penelitian akan lebih variatif. Penelitian diharapkan memberi kontribusi pemikiran untuk membangkitkan kesadaran masyarakat agar mampu melihat media secara kritis. Aspek metodologis, memberikan pedoman dan referensi untuk berbagai pihak terkait dengan ekonomi politik media, sebagai upaya untuk membongkar berbagai dinamika ideologi media daerah melalui hubungan dominasi dan kekuasaan penguasa ekonomi daerah dalam mempengaruhi institusi media daerah dan sebaliknya, sehingga dapat mendorong upaya-upaya untuk membuat regulasi yang bersifat melindungi kepentingan masyarakat dari hegemoni media.

\section{B. METODE PENELITIAN}

Tulisan ini mengkaji tentang ekonomi politik media cetak daerah pada tingkat strukturasi. Media cetak sebagai objek kajian ini adalah Kridha Rakyat. Kajian ini berada dalam paradigma konstruktivis. Paradigma konstruktivisme itu bersifat reflektif atau dialektikal, peneliti dan subyek yang diteliti melakukan empati dan interaksi dialektis agar mampu mengonstruksi realitas yang diteliti melalui metode kualitatif. Sifat hubungan epistemologi penelitian ini, antara pengamat dan subyek merupakan satu kesatuan, subyektif, dan merupakan hasil perpaduan interaksi antara keduanya. Meminjam pendapat Guba dan Lincoln (1994) paradigma konstruktivisme penelitian ini,secara ontologis memandang ilmu sosial sebagai analisis sistematis terhadap tindakan sosial (social meaningful action) melalui pengamatan langsung dan rinci terhadap pelaku sosial yang membangun realitanya sendiri. Berdasarkan paradigma konstruktivisme, secara ontologi kebenaran dimaknai sebagai sesuatu yang relatif sehingga peneliti yang mengkonstruksi kebenaran tersebut. Secara epistimologi relasi yang terjalin antara peneliti dan yang diteliti terjadi secara transaksional. Secara Aksiologi penelitian ini melibatkan peneliti dalam observasi partisipatif, sehingga dapat menemukan secara langsung pola interaksi yang menuju rekonstruksi kebenaran (Guba dan Lincoln, 1994:120).

Sifat penelitian ini adalah kualitatif dan menggunakan jenis penelitian naratif eksploratif sebagai cara penyampaian laporan. Menurut Lexy J. Moleong (2002) penelitian kualitatif adalah penelitian yang berdasarkan pada pondasi penelitian, paradigma penelitian, perumusan masalah, tahap-tahap penelitian, teknik penelitian, kriteria dan teknik pemeriksaan data dan analisis dan penafsiran data. Selain itu juga penelitian kualitatif merupakan penelitian yang bermaksud memahami fenomena tentang apa yang dialami oleh subyek penelitian misalnya perilaku, persepsi, motivasi, tindakan, dan lain-lain, secara holistik, dan dengan cara deskripsi dalam bentuk kata-kata dan bahasa, pada suatu konteks khusus yang alamiah dan dengan memanfaatkan berbagai metode alamiah. Sedangkan ciri naratif eksploratif adalah penyampaian yang berbentuk penceritaan dan menggali sedalam mungkin hasil temuan di lapangan. Menurut Kriyantono (2010:69), eksploratif di sini bertujuan untuk menggali data tanpa mengoperasionalisasi konsep atau menguji konsep pada realitas yang diteliti. Dalam penelitian kualitatif data-data dapat berasal dari banyak format, seperti wawancara, observasi, dokumen, seperti yang dijelaskan Cresswell,

“...qualitative researcher typically gather multiple forms of data, such as interviews, observation, and document, rather than rely on a single data source. Then the researcher review all of the data, make sense of it, and organized it into categories or themes that cut across all of the data sources" (Creswell, $2009: 164$ ).

Dalam penerapannya, setiap dinamika ideologi yang tampak (manifest) maupun pesan yang tersembunyi (latent message) yang terdapat dalam konstrusi berita media cetak Kridha Rakyat dimasukkan dalam kategori yang telah ditetapkan kedalam coding sheet (lembar kerja koding). Data tersebut kemudian dianalisis menggunakan metode analisis isi kualitatif untuk mendapatkan dan menentukan dinamika ideologi dari setiap kategori tema penelitian. Hasil dari kategori tersebut nantinya akan disajikan dalam tabel induk atau tabel hasil penelitian dinamika ideologi, bertujuan agar data yang ditemukan lebih terperinci dan maksimal.

\section{HASIL DAN PEMBAHASAN}

Strukturasi merupakan interaksi interdependensi antara agen dengan struktur sosial dimana agen itu berada. Hasil akhirnya adalah serangkaian hubungan sosial dan proses kekuasaan yang terorganisir di antara kelas, gender, ras, dan gerakan sosial, yang semuanya saling berhubungan. Analisis yang digunakan adalah teori strukturasi Vincent Mosco yaitu dengan memberi penjelasan adanya dualitas bukan dualisme antar struktur dan individu. Obyek utama bukanlah peran sosial seperti dalam fungsionalisme, bukan pula kode tersembunyi seperti dalam strukturalisme Levi-Strauss, bukan pula seperti keunikan situasional seperti dalam interaksi 
Website : http://yustisia.unmermadiun.ac.id/index.php/yustisia

simbolik Goffman. Dalam strukturasi obyek bukan bagian dan bukan keseluruhan, bukan struktur dan bukan pula individu, tetapi merupakan titik temu antara keduanya.

Praktik dan pola aturan (rules) Kridha Rakyat, meminjam pendapat Gillian Doyle (2002: 172) menjadi konsentrasi dan kepemilikan media adalah resiko bagi demokrasi dan bagi sistem politik yang lebih besar ketika pemilik media mendapatkan kontrol yang lebih. Pemilik media Kridha Rakyat melakukan kontrol pada distribusi media cetaknya supaya sampai kepada readership. Komponen utama yang membentuk berita di Kridha Rakyat berupa teras berita (lead) ditulis dengan pola piramida terbalik yaitu mulai dari bagian paling penting (teras) makin ke bawah makin kurang penting. Berita di Kridha Rakyat (tabel 1) termasuk kategori berita- berita langsung (straight news). Bagian paling atas (alinea pertama) lead/inti berita, merupakan bagian fakta paling penting. Penulisan berusaha menggunakan cover both side, berusaha seimbang dan berusaha mencantumkan semua pihak yang terlibat dalam peristiwa.

Hasilnya, kegiatan kepala dinas/pimpinan instansi dimuat dalam edisi sebagai produk aktifitas. Menjadi alat praktik penyampaian dan kesadaran antaragen dalam pemberitaan. Media mempunyai legitimasi atas pemberitaan, struktur berubah dan tereproduksi sebagai struktur baru yang lebih menonjolkan sebuah peran. Dimana dominasi terlihat dari sebuah struktur yang terbentuk diantara hubungan agen-agen di dalam pemberitaan media. Kemudian signifikasi mengacu pada wacana-wacana yang dibangun oleh agen untuk melancarkan segala usaha demi tercapainya segala tujuan ekonomi media. Kemudian pada dominasi atas ekonomi media akan diperoleh ketika semua usaha mencapai tujuan ekonomi tersebut. Difasilitasi dan dilegitimasi oleh kebijakan-kebijakan dari media dan menguntungkan medianya maupun pada pimpinan istansi yang diberitakan.

Tabel 1.

Judul dan Lead Kridha Rakyat

\begin{tabular}{|c|c|c|}
\hline $\begin{array}{l}\text { Edisi/ } \\
\text { Rubrik }\end{array}$ & Judul Berita & and \\
\hline 692 / Madiun & $\begin{array}{l}\text { Pemkot Madiun } \\
\text { persiapkan PPID Kota } \\
\text { Madiun berikan } \\
\text { pelayanan informasi } \\
\text { lebih baik }\end{array}$ & $\begin{array}{l}\text { Era keterbukaan sekarang ini, } \\
\text { menuntut badan publik untuk } \\
\text { dapat mengelolah dan mengemas } \\
\text { informasi yang dimilikinya dengan } \\
\text { cara yang baik. Berdasarkan UU } \\
\text { No. } 14 \text { tahun } 2008 \text { tentang } \\
\text { keterbukaan informasi publik, } \\
\text { setiap badan publik diwajibkan } \\
\text { untuk menunjuk pejabat pengelola } \\
\text { informasi dan dokumentasi } \\
\text { (PPID). PPID dituntut untuk } \\
\text { menguasai cara mengelola } \\
\text { informasi publik dan } \\
\text { pengemasannya } \\
\text { ditampilkan diranah umum. }\end{array}$ \\
\hline
\end{tabular}

692/ Ngawi Bupati H. Budi Bupati Ngawi Budi Sulistiyono Sulistyono harapkan (Kanang) resmikan Cunthang optimalisasi wisata sebagai lokasi wisata river Tubing masyarakat. pertama di Ngawi, Rabu (17/05/2017). Apresiasi besar diberikan oleh bupati Ngawi atas peresmian lokasi wisata tersebut.

\section{Tubuh Berita/Kutipan}

\author{
Agus Dwi M, kepala seksi \\ layanan informasi publik dinas \\ kominfo Jatim, menyampaikan \\ materi berjudul" eksisitensi PPID \\ badan publik"
}

Komisioner Kominsi Informasi (KI) Provinsi Jatim, Isrowi Farida menyampaikan standar layanan informasi dan prosedur penyelesaian sengketa informasi.
Kanang dalam sambutannya menjanjikan akan mendukung perbaikan fasilitas penunjang wisata seperti halnya perbaikan jalan dan sejenisnya."ke depan akses jalan akan diperbaiki untuk mendukung wisata, Taman Wisata Segawen akan diwujudkan untuk mendukung potensi alam permainan anak, adventure sepeda, dan offroad jeep" ungkapnya sebagaimana diberikan Kampoeng Ngawi.

Sumber : Diolah dari data observasi Kridha Rakyat

Berita yang dimuat di Kridha Rakyat melalui proses pengolahan dari tahap pencarian hingga informasi menjadi berita. Diksi dan tata bahasa pada judul nampak struktur informasi menekankah kepada aktor. Seperti Volume 4 Nomor 2 September 2018, YUSTISIA MERDEKA | 93 
Website : http://yustisia.unmermadiun.ac.id/index.php/yustisia

pada judul "Bupati H. Budi Sulistyono harapkan optimalisasi wisata masyarakat". Gaya penulisan lead dalam berita menonjolkan objek dalam cerita (sikap aktor). Seperti pada lead "Bupati Ngawi Budi Sulistiyono (Kanang) resmikan Cunthang sebagai lokasi wisata river Tubing pertama di Ngawi, Rabu (17/05/2017). Apresiasi besar diberikan oleh bupati Ngawi atas peresmian lokasi wisata tersebut”. Struktur penulisan berita terlihat menekankan pada kutipan kalimat langsung Aktor (tokoh) dan dianggap yang paling penting. Seperti pada teras berita edisi 692:

Kanang dalam sambutannya menjanjikan akan mendukung perbaikan fasilitas penunjang wisata seperti halnya perbaikan jalan dan sejenisnya. "ke depan akses jalan akan diperbaiki untuk mendukung wisata, Taman Wisata Segawen akan diwujudkan untuk mendukung potensi alam permainan anak, adventure sepeda, dan offroad jeep" ungkapnya sebagaimana diberikan Kampoeng Ngawi.

Artinya, bagi Kridha Rakyat, nilai berita menjadi hal penting pada sisi magnitude, bahwa berita tentang Bupati diharap memberi pengaruh besar kepada pembaca ketika berita tersebut diberitakan. Tema Bupati dianggap memilki significance, dinilai sebagai peristiwa penting bagi masyarakat. Dilihat pada sisi nilai berita proximity (kedekatan), pertimbangan Kridha Rakyat memuat berita adalah wilayah distribusi. Seperti berita kegiatan Bupati Ngawi, secara kedekatan geografis Ngawi dekat dengan Madiun. Sedangkan kedekatan psikologis diharapkan muncul apabila sering diberitakan tentang Bupati. Human interest belum menonjol menjadi penekanan nilai berita di Kridha Rakyat, namum prominence (keterkenalan tokoh) selalu menonjol di setiap pemberitaan. Seperti Bupati,Walikota, Gubernur, dan pimpinan instansi lainnya. Hal itu menggambarkan bahwa pemberitaan yang hangat diperbincangkan yang menyangkut tokoh dianggap memiliki timeliness (aktual) oleh Kridha Rakyat. Ditunjukkan dengan pemberitaan-pemberitaan Kridha Rakyat di dominasi berita seputar kegiatan pimpinan pemerintah daerah dan pimpinan instansi lainnya. Secara struktur dominasi sumber daya di Kridha Rakyat Nampak memproduksi sekaligus mereproduksi struktur dominasi pada sisi berita pimpinan daerah/instansi. Struktur berita seperti itu akan memproduksi tindakan (Kridha Rakyat sebagai aktor) dan pada saat yang sama diproduksi oleh (Kridha Rakyat sebagai agen) untuk di konstitusi sebagai struktur.

Meminjam pemikiran Anthony Giddens dalam The Constitusion of Society (1984) mengungkapkan, ada dua sumber daya yang membentuk struktur dominasi, yakni sumber daya alokatif dan otoritatif. Sumber daya alokatif Kridha Rakyat menyangkut penguasaan barang-barang yang bersifat materiil atau ekonomi. Sedangkan sumber daya otoritatif di Kridha Rakyat berkaitan dengan penguasaan terhadap individual (masyarakat/khalayak/pembaca) atau institusional (lembaga pemerintahan) secara politis. Hasrat berkuasa seseorang cenderung didorong libido untuk menguasai kedua sumber daya tersebut.

Tradisi struktural media Kridha Rakyat, Meminjam pendapat Giddens, struktur merupakan aturan (rules) dan sumberdaya (resources) yang terbentuk dari dan perulangan praktik sosial (Giddens, 1976,1993:126, 1979:63, 1984:xxxi). Dualitas antara struktur dan pelaku terletak pada proses di mana struktur sosial merupakan hasil (outcome) dari praktek sosial. Selain itu struktur sekaligus merupakan sarana (medium) yang memungkinkan berlangsunganya praktek sosial (Giddens. 1976, 1993:128-129, 1979:5, 1984:374). Struktur bukanlan bersifat mengekang (constraining) seperti pada pengertian Dhurkheimian. Tetapi struktur dalam Kridha Rakyat memiliki sifat memberdayakan (eabling) yang memungkinkan praktek sosial.

Dengan pendekatan teori strukturasi terlihat perbedaan antara struktur dengan sistem di medianya. Struktur Nampak pada sintagmatik dan paradigmatik dalam penstrukturan hubungan-hubungan sosial. Dimensi sintagmatik dapat dilihat dari resproduksi praktek-praktek yang terikat pada ruang dan waktu tertentu di Kridha Rakyat. Sementara itu dimensi paradigmatik dapat dilihat dari tata cara-cara penstrukturan yang terjadi berulang kali dalam proses reproduksi berita dan iklan di medianya. Hal ini, karena struktur merujuk pada sifat-sifat penstrukturan yang memberikan bentuk sistemik pada kegiatan-kegiatan sosial serupa dan yang memungkinkan mereka bertahan dalam lintas ruang dan waktu (Suhartono, dalam: Basis 2000).

Sementara itu sistem-sistem sosial merujuk pada praktek-praktek sosial yang direproduksikan (Gidddens. 1984:17). Praktek-praktek sosial yang direproduksikan di Kridha Rakyat adalah kegiatan-kegiatan yang terikat pada ruang dan waktu tertentu yang diadakan kembali dalam lintas ruang dan waktu yang secara berulang melibatkan struktur di dalamnya (table 2). Karenanya struktur mengatasi ruang dan waktu. Struktur hanya ada dalam perwujudan seketika dalam sistem sosial dan jejak-jejak ingatan bagi orientasi perilaku manusia. Karenanya struktur bukan berada di luar individu. Giddens mendefinisikan strukturasi sebagai strukturasi relasirelasi sosial yang melintasi waktu dan ruang berkat adanya dualitas struktur. Strukturasi adalah proses praktekpraktek sosial menjadi struktur yang hanya bisa terjadi dalam lintas ruang dan waktu. Giddens memandang ruang dan waktu secara integral turut membentuk kegiatan sosial. (Giddens, 1984:142).

Apabila diamati dari teks judul di pemberitaan "Pemkot Madiun persiapkan PPID Kota Madiun berikan pelayanan informasi lebih baik" dan "Bupati H. Budi Sulistyono harapkan optimalisasi wisata masyarakat" 
Website : http://yustisia.unmermadiun.ac.id/index.php/yustisia

Nampak relasi ide antar agen. Kemampuan memberdayakan (enabling) terlihat bahwa antara agen (pemilik media dan sumber berita) dan struktur (media dan instansi yang diberitakan) saling melengkapi dan mempengaruhi realitas tanpa menegasikan satu dengan yang lain. Struktur menjadi medium dan hasil dari tindakan agen yang dilakukan berulang-ulang (terdapat berita tentang kegiatan institusi yang sama di edisi yang lain). Sedangkan agen, menunjukkan bahwa tiap orang memiliki kemampuan pemahaman yang cukup dan kompeten, dan merefleksikan tiap tindakannya.

Tabel 2

Pengiklan Kridha Rakyat

\begin{tabular}{|c|c|c|c|}
\hline Wilayah & Instansi/Pengiklan & Iklan & Edisi \\
\hline \multirow[t]{23}{*}{ Madiun } & Dinas Ketahanan Pangan Kabupaten Madiun & Selamat Tahun Baru 2017 & 672 \\
\hline & Inspektorat Pemerintah Kabupaten Madiun & Selamat Tahun Baru 2017 & 672 \\
\hline & Badan Pendapatan Daerah Kabupaten Madiun & Selamat Tahun Baru 2017 & 672 \\
\hline & $\begin{array}{l}\text { Dinas Pengendalian Penduduk KB, Pemberdayaan Perempuan dan } \\
\text { Perlindungan Anak Kabupaten Madiun }\end{array}$ & Selamat Tahun Baru 2017 & 672 \\
\hline & Dinas Pemberdayaan Masyarakat dan Desa Kabupaten Madiun & Selamat Tahun Baru 2017 & 672 \\
\hline & Dinas Perhubungan Pemerintah Kabupaten Madiun & Selamat Tahun Baru 2017 & 672 \\
\hline & Dinas Tenaga Kerja Pemerintah Kabupaten Madiun & Selamat Tahun Baru 2017 & 672 \\
\hline & $\begin{array}{l}\text { Dinas Kependudukan dan Pencatatan Sipil Pemerintah Kabupaten } \\
\text { Madiun }\end{array}$ & Selamat Tahun Baru 2017 & 672 \\
\hline & Dinas Pertanian dan Perikanan Pemerintah Kabupaten Madiun & Selamat Tahun Baru 2017 & 672 \\
\hline & $\begin{array}{l}\text { Dinas Perdagangan, Koperasi dan Usaha Mikro Pemerintah } \\
\text { Kabupaten Madiun }\end{array}$ & Selamat Tahun Baru 2017 & 672 \\
\hline & SMAN 1 Nglames Kabupaten Madiun & Selamat Tahun Baru 2017 & 672 \\
\hline & DPRD Kabupaten Madiun & Selamat Tahun Baru 2017 & 672 \\
\hline & Bagian Humas dan Protokol Pemerintah Kabupaten Madiun & Selamat Tahun Baru 2017 & 672 \\
\hline & SMKN 1 Wonoasri Kabupaten Madiun & Selamat Tahun Baru 2017 & 672 \\
\hline & SMAN 2 Mejayan Kabupaten Madiun & Selamat Tahun Baru 2017 & 672 \\
\hline & $\begin{array}{l}\text { Dinas Perumahan dan Kawasan Permukiman Pemerintah } \\
\text { Kabupaten Madiun }\end{array}$ & Selamat Tahun Baru 2017 & 672 \\
\hline & Dinas Komunikasi dan Informatika Pemerintah Kabupaten Madiun & Selamat Tahun Baru 2017 & 672 \\
\hline & Dinas Kesehatan Pemerintah Kabupaten Madiun & Selamat Tahun Baru 2017 & 672 \\
\hline & Dinas Sosial Pemerintah Kabupaten Madiun & Selamat Tahun Baru 2017 & 672 \\
\hline & $\begin{array}{l}\text { Dinas Pekerjaan Umum dan Penataan Ruang Pemerintah } \\
\text { Kabupaten Madiun }\end{array}$ & Selamat Tahun Baru 2017 & 672 \\
\hline & Dinas Pendidikan dan Kebudayaan Pemerintah Kabupaten Madiun & Selamat Tahun Baru 2017 & 672 \\
\hline & $\begin{array}{l}\text { Badan Kesatuan Bangsa dan Politik Dalam Negeri Pemeritah } \\
\text { Kabupaten Madiun }\end{array}$ & Selamat Tahun Baru 2017 & 672 \\
\hline & Badan Perencanaan Pembanguan Daerah Pemerintah Kabupaten & Selamat Tahun Baru 2017 & 672 \\
\hline
\end{tabular}


Website : http://yustisia.unmermadiun.ac.id/index.php/yustisia

\author{
Madiun \\ Badan Kepegawaian Daerah Pemerintah Kabupaten Madiun \\ Kabupaten Madiun \\ KODIM 0803 Madiun \\ Desa Sidomulyo Kec. Wonoasri Pemerintah Kabupaten Madiun \\ SMPN 1 Saradan Kabupaten Madiun \\ Lembaga Pemasyarakatan Klas 1 Madiun \\ IKIP PGRI Madiun \\ Kantor Kementrian Agama Kabupaten Madiun \\ Kabupaten Madiun Kecamatan Dagangan \\ Kimura Karaoke Pub \& Resto Jl.Progo No.01 Kota Madiun
}

Badan Pengelolaan Keuangan dan Aset Daerah Pemerintah Selamat Tahun Baru 2017

Kantor Kementerian Agama Kabuapten Madiun

Toko TV/Radio dan Elektronik "CHANDRA"

Kantor Kemntrian Agama Kabupaten Madiun

\section{Hoki Dimsum}

Ponorogo Badan Perencanaan Pembangunan Daerah Pemerintah Kabupaten Ponorogo

Dinas Kesehatan Pemerintah Kabupaten Ponorogo

Dinas Pariwisata Pemerintah Kabupaten Ponorogo

Dinas Pengendalian Pendudukan Dan Keluarga Berencana

Pemerintah Kabupaten Ponorogo

Badan Kepegawaian, Pendidikan Dan Pelatihan Daerah Pemerintah Kabupaten Ponorogo

Badan Pendapatan, Pengelolaan Keuangan Dan Asset Daerah Pemerintah Kabupaten Ponorogo

Badan Kesatuan Bangsa Pemerintah Kabupaten Ponorogo

Badan Perencanaan Pembangunan Daerah Pemerintah Kabupaten Ponorogo

Dinas Perhubungan Pemerintah Kabupaten Ponorogo

Pertanian Dan Perikanan Pemerintah Kabupaten Ponorogo

Dinas Pekerjaan Umum Dan Penataan Ruang Pemerintah
Selamat Tahun Baru 2017

Selamat Natal dan Tahun Baru 2017

Selamat Natal dan Tahun Baru 2017

Selamat Natal dan Tahun Baru 2017

673

Selamat Natal dan Tahun Baru 2017

Tahun Baru 2017

Selamat hari amal bhakti kementrian agama ke 71 tahun 2017

Ucapkan terima kasih

Mengucapkan Selamat Tahun Baru Imlek 2568/2017 Gong Xi Fa Cai

selamat hari amal bhakti kementrian agama ke 71 tahun 2017

Mengucapkan Selamat Tahun Baru Imlek 2568/2017 Gong Xi Fa Cai

selamat hari amal bhakti kementrian agama ke 71 tahun 2017

Mengucapkan Selamat Tahun Baru Imlek 2568/2017 Gong Xi Fa Cai

Selamat Natal dan Tahun Baru 2017

Selamat Natal dan Tahun Baru 2017

Selamat Natal dan Tahun Baru 2017

Selamat Natal dan Tahun Baru 2017

Selamat Natal dan Tahun Baru 2017

Selamat Tahun Baru 2017

Selamat Tahun Baru 2017

Selamat Tahun Baru 2017

Selamat Natal dan Tahun Baru 2017

Selamat Natal dan Tahun Baru 2017

673

Selamat Natal dan Tahun Baru 2017 
Website : http://yustisia.unmermadiun.ac.id/index.php/yustisia

\begin{tabular}{|c|c|c|c|}
\hline & Kabupaten Ponorogo & & \\
\hline & $\begin{array}{l}\text { Dinas Kependudukan Dan Pencatatan Sipil Pemerintah Kabupaten } \\
\text { Ponorogo }\end{array}$ & Selamat Natal dan Tahun Baru 2017 & 673 \\
\hline & Badan Keluarga Berencana Pemerintah Kabupaten Ponorogo & Selamat Natal dan Tahun Baru 2017 & 673 \\
\hline & $\begin{array}{l}\text { Dinas Pemberdayaan Masyarakat Dan Desa Pemerintah Kabupaten } \\
\text { Ponorogo }\end{array}$ & Selamat Natal dan Tahun Baru 2017 & 673 \\
\hline & $\begin{array}{l}\text { Dinas Perdagangan, Koperasi Dan Usaha Mikro Pemerintah } \\
\text { Kabupaten Ponorogo }\end{array}$ & Selamat Natal dan Tahun Baru 2017 & 673 \\
\hline Ngawi & Dinas Sosial Pemerintah Kabupaten Ngawi & Selamat Natal dan Tahun Baru 2017 & 673 \\
\hline & $\begin{array}{l}\text { Dinas Pemberdayaan Masyarakat dan Desa Pemerintah Kabupaten } \\
\text { Ngawi }\end{array}$ & Selamat Natal dan Tahun Baru 2017 & 673 \\
\hline & Dinas Perhubungan Pemerintah Kabupaten Ngawi & Selamat Natal dan Tahun Baru 2017 & 673 \\
\hline & $\begin{array}{l}\text { Pemerintah Kabupaten Ngawi Dinas Perumahan Rakyat Dan } \\
\text { Pemukiman }\end{array}$ & Selamat Natal dan Tahun Baru 2017 & 673 \\
\hline & $\begin{array}{l}\text { Dinas Penanaman Modal Dan Pelayanan Perijinan Terpadu Satu } \\
\text { Pintu Pemerintah Kabupaten Ngawi }\end{array}$ & Selamat Natal dan Tahun Baru 2017 & 673 \\
\hline & Dinas Pendidikan Pemerintah Kabupaten Ngawi & Selamat Natal dan Tahun Baru 2017 & 673 \\
\hline & $\begin{array}{l}\text { Dinas Perdagangan, Perindustrian dan Tenaga Kerja Pemerintah } \\
\text { Kabupaten Ngawi }\end{array}$ & Selamat Natal dan Tahun Baru 2017 & 673 \\
\hline & Dinas Perpustakaan Dan Kearsipan Pemerintah Kabupaten Ngawi & Selamat Natal dan Tahun Baru 2017 & 673 \\
\hline & $\begin{array}{l}\text { Dinas Kependudukan Dan Pencatatan Sipil Pemerintah Kabupaten } \\
\text { Ngawi }\end{array}$ & Selamat Natal dan Tahun Baru 2017 & 673 \\
\hline & Dinas Pangan Dan Perikanan Pemerintah Kabupaten Ngawi & Selamat Natal dan Tahun Baru 2017 & 673 \\
\hline & $\begin{array}{l}\text { Dinas Pariwisata, Pemuda Dan Olahraga Pemerintah Kabupaten } \\
\text { Ngawi }\end{array}$ & Selamat Natal dan Tahun Baru 2017 & 673 \\
\hline & $\begin{array}{l}\text { Badan Kepegawaian, Pendidikan Dan Pelatihan Pemerintah } \\
\text { Kabupaten Ngawi }\end{array}$ & Selamat Natal dan Tahun Baru 2017 & 673 \\
\hline & Dinas Pu Dan Tata Ruang Pemerintah Kabupaten Ngawi & Selamat Natal dan Tahun Baru 2017 & 673 \\
\hline & Institut Agama Islam (IAI) Ngawi & Selamat Natal dan Tahun Baru 2017 & 673 \\
\hline & SMP 5 Ngawi & Tahun Baru 2017 & 674 \\
\hline & $\begin{array}{l}\text { Sekolah Tinggi Keguruan dan Ilmu Pendidikan STKIP PGRI } \\
\text { Ngawi }\end{array}$ & $\begin{array}{l}\text { Mengucapkan Selamat dan Sukses } \\
\text { Kepada Wisudawan }\end{array}$ & 675 \\
\hline
\end{tabular}

Sumber : Diolah dari data rubik edisi 672-675 di Kridha Rakyat

Berdasarkan tabel 2 nampak bahwa banyak pengiklan yang memasang iklan tetapi konten iklanya sama. Dari hasil wawancara strategi menjual space iklan di Kridha Rakyat yaitu dengan menawarkan kepada para pengiklan. Market coverage sesuai cakupan wilayahnya, menjangkau daerah-daerah di Jawa Timur, khususnya Madiun, Ngawi, Magetaan, Ponorogo, dan Pacitan. Iklan display penawaran (Iklan Ucapan) merupakan iklan yang paling dominan di Kridha Rakyat. Ukurannya sangat bervariasi, mulai dari 2 kolom kali 5 sentimeter hingga 1/4, 1/2, dan 1 halaman penuh warna. Wartawan sebagai petugas yang mengirimkan penawaran format iklan ucapan kepada instansi. 
Website : http://yustisia.unmermadiun.ac.id/index.php/yustisia

Berdasarkan pendekatan strukturasi, individu (wartawan dan pemilik media) Kridha Rakyat bukanlah ditempatkan pada posisi titik pusat (decentred subject) tetapi juga bukan subyek dalam lingkup semesta kosong tanda-tanda. Dalam kaitan ini Giddens melihat adanya titik temu antara kegiatan sosial mencekeram ruang dan waktu dengan akar pembentukan dari subyek maupun obyek (Giddens, 1984:xxii). Seluruh kehidupan sosial Kridha Rakyat terjadi dalam dan dibentuk oleh persimpangan kehadiran dan ketidakhadiran dalam waktu dan ruang. Karenanya kehidupan sosial dikontekstualitaskan dengan ruang dan waktu. Dalam kontekstualitas ruang dan waktu di Kridha Rakyat manusia/wartawan dipandang sebagai suatu proses yang terus menerus bukan sebagai kumpulan tindakan atau tindakan yang terpisah-pisah. Konsep-konsep seperti maksud, alasan, sebab dan rasionalisasi dalam pandangan Giddens dilihat sebagai suatu proses bukan keadaan (Giddens, 1984:3). Tindakan wartawan tak dapat dipisahkan dari tubuh media Kridha Rakyat dengan penempatannya dalam dimensi waktu dan ruang. Dengan kata lain interaksi sosial atau kehidupan sosial terlihat dan dapat dipelajari dalam kehadiran bersama di Kridha Rakyat.

Giddens membedakan tiga dimensi waktu, yaitu pengalaman sehari-hari, jangka hidup individual dan lembaga-lembaga (Gidens, 1984:35). Dimensi pengalaman berkaitan dengan waktu yang terbentuk dalam kegiatan atau pengalaman sehari-hari yang dapat dibalik. Dimensi jangka hidup individual berkaitan dengan rentang waktu kehidupan individu yang tak dapat dibalik atau disebut sebagai waktu tubuh. Dimensi lembagalembaga berkaitan dengan waktu keberlangsungan jangka panjang dan dapat dibalik dari lembaga. Dimensi waktu yang berkaitan dengan lembaga ini merupakan waktu kelembagaan yang merupakan baik syarat (condition) maupun hasil (outcome) kegiatan-kegiatan yang terpola dalam keberlangsungan hidup sehari-hari. Dalam konteks ini maka sejarah Kridha Rakyat dipahami sebagai pengertian temporalitas kegiatan-kegiatan manusia yang terjadi dalam keterkaitan tiga dimensi waktu yaitu pengalaman sehari-hari di media, jangka hidup media dan lembaga-lembaga yang terkait dengan kehidupan media.

Konsep lain dalam strukturasi di Kridha Rakyat adalah rutinisasi (routinization). Sesuatu yang rutin inilah yang menjadi elemen dasar kegiatan sosial hari per hari di Kridha rakyat. Apa yang rutin ini menunjukkan adanya keterulangan kegiatan sosial dalam lintas waktu-ruang di Kridha Rakyat. Menurut Giddens apa yang rutin dari suatu kehidupan sosial ini yang menjadi bahan dasar bagi apa yang disebutnya sebagai hakekat keterulangan kehidupan sosial (Giddens, 1984:xxiii). Dari keterulangan ini maka sifat-sifat terstruktur dari kegiatan sosial yang terus menerus diciptakan kembali dari sumber-sumber daya yang dibentuk oleh Kridha Rakyat. Ditunjukkan dengan relasi pemasang iklan di tiap wilayah akan dapat dimuat kembali di edisi yang lain. Sementara itu untuk memahami ruang Kridha Rakyat maka seperti menyadari posisi tubuh. Dalam kerangka pemikiran Giddens, tubuh dipandang sebagai sebagai tempat kedudukan diri yang aktif (the locus of the active self) (Giddens,1984:36). Dalam kehidupan sehari-hari individu-individu yan bekerja di redaksi Kridha Rakyat bertemu dengan individu-individu lainnya yang hadir bersama secara fisik dan interaksi yang terikat pada konteks situasi. Cirikhas sosial adalah kehadiran di Kridha Rakyat berakar pada spasialitas tubuh yang terarah pada diri sendiri maupun kepada orang lain. Giddens melihat pada posisi tubuh manusia ketika hadir dalam interaksi tidak menempati ruang dan waktu seperti halnya benda-benda material dalam ruang dan waktu. Tetapi spasialitas tubuh manusia merujuk pada situasi aktif yang terarah pada tugas-tugasnya (Giddens, 1984:65). Karenanya posisi tubuh menurut Giddens harus dipahami sebagai pengambilan posisi dalam kehadiran bersama.

Menurut Giddens dalam prinsip struktural terdapat tiga gugus besar struktur, yaitu signifikasi (signification), dominasi (domination) dan legitimasi (legitimation)((Giddens, 1979:82, 1984:29-33). Struktur signifikasi atau penandaan adalah struktur yang menyangkut simbolik, pemaknaan, penyebutan dan wacana. Sedangkan struktur dominasi atau penguasaan di Kridha rakyat mencakup penguasaan atas orang dan barang. Penguasaan atas orang berkaitan dengan politik. Sementara penguasaan terhadap barang berkaitan dengan bidang ekonomi. Struktur legitimasi atau pembenaran menyangkut peraturan normatif yang terungkap dalam tata hukum (Giddens, dalam Herry-Priyono, 2002:24). Struktur dominasi di Kridha Rakyat mengacu pada hubungan asimetri pada tataran struktur, sementara itu kekuasaan menyangkut kapasitas yang terlibat dalam hubungan sosial pada tataran praktek sosial. Menurut Giddens kekuasaan dilihat sebagai transformatif capacity (Giddens, 1979:92). Kapasitas transformatif adalah kemampuan mengadakan intervensi dalam peristiwa tertentu dan mengadakan perubahan. Karena itu kekuasaan akan tampak ketika digunakan dalam struktur (Giddens, 1979:91). Sementara itu ada dua macam sumber daya yang terlibat dalam membentuk struktur dominasi, yaitu sumberdaya alokatif dan otoritatif (Giddens, 1979:100). Pertama, sumber daya alokatif yaitu yang memungkinkan dominasi manusia atas dunia material. Sumber alokatif ini di Kridha Rakyat meliputi bahan mentah percetakan media, peralatan produksi percetakan, teknologi yang digunakan, hasil-hasil produksi media cetak. Kedua, adalah sumber daya otoritatif. Sumber daya ini yang memungkinkan dominasi manusia atas dunia 
Website : http://yustisia.unmermadiun.ac.id/index.php/yustisia

sosial. Sumber daya otoritatif di Kridha Rakyat seperti pengorganisasian ruang-waktu, organisasi dan relasi manusia dalam asosiasi timbal balik, pengorganisasian kemungkinan kehidupan, ketika menggunakan dua sumber daya tersebut.

Kekuasaan dalam struktur Kridha Rakyat di dalamnya terdapat apa yang disebut sebagai rules dan resources baik pada sumber daya alokatif maupun sumber daya otoritatif. Resources Kridha Rakyat merupakan media kekuasaan pada tataran praktis dan sekaligus media struktur dominasi yang direproduksikan. Peran resources (pengiklan) merupakan faktor vital bagi individu dalam mewujudkan kekuasaan medianya. Resources di Kridha Rakyat inilah yang memampukan individu untuk melakukan dominasi dengan pihak lain. Atau dengan kata lain dengan resources individu telah menciptakan struktur dominasi. Tiga gugus prinsip struktural, pada tataran praktek sosial ketiganya di Kridha Rakyat saling kait mengkait yaitu signifikasi (signification), dominasi (domination) dan legitimasi (legitimation). Terlihat Media sebagai penyalur pesan dan subjek dalam konstruksi berita dan iklan memiliki pandangan sendiri dan keberpihakan. Media secara aktif membentuk realitas sosial dengan mengambil framing dari suatu kejadian untuk diberitakan dan diiklankan kepada masyarakat. Media memilih peristiwa dan sumber berita sekaligus mendefinisikan peristiwa dan sumber berita menurut medianya.

Dari hasil wawancara dengan redaksi, strategi kekuatan Kridha Rakyat dalam proses pemberitaan adalah dengan penawaran berita/iklan advertorial. Serangkaian hubungan proses pemuatan berita/iklan ditawarkan media kepada para pengiklan di Ponorogo, Magetan, Ngawi, Pacitan dan Madiun. Iklan ucapan menjadi ciri khas setiap terbit di Kridha Rakyat, meliputi kegiatan pemrintah dan peringatan hari khusus seperti pada tabel 2. Iklan ucapan mislanya meliputi ucapan hari natal, tahun baru dan ucapan selamat dan sukses. Beberapa iklan ucapan tersebut berasal dari instansi pemerintah/lembaga. Penggambaran perubahan sosial terlihat pada konten berita dan iklan yang sebagian besar berasal dari instansi-instansi/lembaga tersebut. Serangkaian hubungan sosial menunjukkan proses kekuasan dengan model "simbiosis mutualisme". Artinya proses kekuasaan diorganisasikan dalam struktur yang diproduksi dan direproduksi berulang. Mekanisme produksi, konsumsi dan distribusi juga nampak berputar di struktur media yang dibangun oleh media. Penyesuaian hubungan sosial dan proses kekuasaan disesuaikan dengan lingkungan sosial, ekonomi dan politik pada masing-masing wilayah berita/iklan. Tema pemberitaan/iklan akan disesuaikan dengan peristiwa pada permintaan/penawaran struktur di media dan lingkungan.

Sehingga struktur sosial di media menunjukkan bahwa, aturan dan sumberdaya di Kridha Rakyat terbentuk dan membentuk keterulangan praktik sosial (media) dalam membuat berita dan iklan. Struktur sosial Kridha Rakyat adalah hasil sekaligus sarana praktik sosial (media) dalam membuat berita dan iklan. Praktik sosial Kridha Rakyat menunjukkan posisi redaksi sebagai aktor (agen) dalam membuat berita dan iklan. Keterulangan dan/atau keterpolaan praktik sosial Kridha Rakyat dalam membuat berita dan iklan nampak pada struktur medianya.

\section{KESIMPULAN}

Kesimpulan dari penelitian ini antara lain, Media daerah merupakan industri yang berubah dan berkembang di daerah, menciptakan lapangan kerja, barang dan jasa, serta menghidupkan industri lain terkait yang berada di daerahnya. Media daerah merupakan industri tersendiri yang memiliki peraturan dan normanorma yang menghubungkan institusi daerah tersebut dengan masyarakat daerah dan institusi sosial daerah lainnya. Media massa daerah merupakan sumber kekuatan, alat kontrol, manajemen, dan inovasi dalam masyarakat daerah, yang dapat didayagunakan sebagai pengganti kekuatan atau sumber daya lainnya di daerahnya. Media daerah adalah wadah yang menampilkan peristiwa-peristiwa kehidupan masyarakat daerah, dalam hal ini media daerah memberikan efek kognitif bagi masyarakat daerah dalam hal pengetahuan. Media daerah berperan dalam mengembangkan kebudayaan, juga tata cara, mode, gaya hidup dan norma-norma di daerahnya. Media daerah memberikan efek afektif dan behavior di masyarakat daerah.Media daerah menjadi sumber dominan, bukan saja bagi individu untuk memperoleh gambaran dan citra realitas sosial daerah, tetapi juga bagi masyarakat dan kelompok secara kolektif.

Media daerah turut menyuguhkan nilai-nilai dan penilaian normatif yang dibaurkan dengan berita dan hiburan daearh. Keberadaaan media massa daerah dalam menyajikan informasi cenderung memicu perubahan serta banyak membawa pengaruh pada penetapan pola hidup dan perilaku masyarakat daerahnya. Beragam informasi yang disajikan dapat memberi pengaruh yang berwujud positif dan negatif. Secara perlahan-lahan namun efektif, media daerah membentuk pandangan masyarakat terhadap bagaimana seseorang melihat pribadinya dan bagaimana seseorang seharusnya berhubungan dengan dunia sehari-hari.Hubungan antara agensi (individu) daerah dengan struktur sosial daerahnya, yang mana media daerah menjadi bagian darinya adalah 
Website : http://yustisia.unmermadiun.ac.id/index.php/yustisia

hubungan yang simetris dialektis dalam kerangka ruang dan waktu. Agen dan struktur daerah memiliki pola kerja yang sinergis, interdependen, dan karena proses tindakan terjadi secara terpola merintangi ruang dan waktu.

\section{E. UCAPAN TERIMAKASIH}

Penulis mengucapkan terima kasih kepada Kementerian Riset, Teknologi Dan Pendidikan Tinggi Republik Indonesia (Kemenristekdikti) yang telah memberi Beasiswa Pendidikan Pascasarjana Dalam Negeri (BPPDN). Terima kasih juga kepada Yayasan Perguruan Tinggi Merdeka Madiun (YAPERTIMMA) atas pemberian bantuan pembiayaan studi lanjut pascasarjana program doktor (S3). Dengan beasiswa dan bantuan tersebut penulis memiliki kesempatan untuk mempublikasikan hasil penelitian dalam jurnal ini.

\section{F. DAFTAR PUSTAKA}

Creswell, John W. 2009. Research Design : Qualitative, Quantitative, and Mixed Methods Approaches. Newbury Park: Sage Publications. Doyle, Gillian. 2002. Understanding Media Economics. Beverly Hills : Sage Publications

Giddens, Anthony. 2010. Teori Strukturisasi. Yogyakarta: Pustaka Pelajar.

Giddens, Anthony. 2003. Jalan Ketiga dan Kritik-Kritiknya. Yogyakarta: IRCiSoD.

Giddens, Anthony. 1984. Constitution of Society: The Outline of the Theory of Structuration. Cambridge: Polity Press

Giddens, Anthony 1976. New Rules of Sociological Method. California :Stanford University Pers.

Giddens, Anthony. 1993.The Giddens Reader. California :Stanford University Pers.

Giddens. Anthony 1979. Central Problems in Social Theory. USA : University of California Press.

Guba, E.G. \& Lincoln, Y.S, 1994. Competing Paradigms in Qualitative Research In Denzin MK And Lincoln KS. etc. New Delhi : Sage Publications.

Hidayat, Dedy N. 2000. Pers dalam Revolusi Mei: Runtuhnya Sebuah Hegemoni. Jakarta: PT. Gramedia Pustaka Utama.

Kriyantono. 2010. Teknik Praktis Riset Komunikasi : Disertai Contoh Praktis Riset Media, Public Relation, Advertising, Komunikasi Organisasi, Komunikasi pemasaran. Jakarta: Kencana Prenada Media Group.

Littlejohn, Stephen W. 2002. Theories of Human Communication. Seventh. Edition. Wadsworth GroupUnited States of America : Wadsworth Publishing Company.

Littlejohn, Stephen W and Karen A. Foss. 2008. Theories of Human Communication. Ninth Edition. USA: Thomson Higher Education.

Masuki M. Astro. 2016. Indeks Kemerdekaan Pers Di Jawa Timur 2016 Cukup Bagus. www.ubaya.ac.id.

McQuail, Denis. 2002. McQuail's Reader in Mass Communication Theory. London : Sage Pubication.

Moleong, Lexy. 2002. Metodologi Penelitian Kualitatif. Bandung: PT. Remaja Rosdakarya.

Mosco, Vincent. 1996. The Political Economy of Communication: Rethinking and Renewal. London: Sage Publication.

Natsir, Haedar. 2010. Memahami Strukturasi Dalam Perspektif Sosilogi Giddens. Jurnal Sosiology Reflektif. Volume 7 No 1.

Oetama, Jakob. 2001. Pers Indonesia: Berkomunikasi dalam Masyarakat Tidak Tulus. Jakarta: Penerbit Buku Kompas.

Presiden Republik Indonesia. 1999. Undang-Undang Nomor 40 Tahun 1999 tentang Pers. Jakarta.

Ritzer, George dan Douglas J. Goodman. 2008. Teori Soisologi Modern. Jakarta : Prenada. Media.

Rogers, Everett. M. 1994. A History of Communication Study: A. Biographical Approach. New York: The Free Press.

Stevenson, N. 2002. Understanding Media Cultures. London: Sage Publication.

Sularto, St. 2011. Syukur Tiada Akhir, Jejak Langkah Jakob Oetama. Jakarta: Penerbit Buku Kompas.

Tim LSPP. 2005. Media Sadar Publik : Media Lokal Mewartakan Korupsi dan Pelayanan Publik. Jakarta: LSPP dan Open Society. Tim Peneliti Dewan Pers. 